\title{
NECESSITY OF SOCIAL FINGERPRINT AS AN EFFECTIVE INTERNAL CONTROL SYSTEM IN TURKISH BUSINESSES
}

DOI: 10.17261/Pressacademia.2021.1439

PAP- V.13-2021(28)-p.111-112

Ozgen Tukel ${ }^{1}$, Murat Adil Salepcioglu ${ }^{2}$

${ }^{1}$ Istanbul Aydın University, Institute of Graduate Studies, Department of Quality Mng and Quality Assurance Systems, Istanbul, Turkey. ozgentukel@stu.aydin.edu.tr, ORCID: 0000-0002-5895-0709

${ }^{2}$ Istanbul Aydın University, Faculty of Economics and Administrative Sciences, Departmant of Business Administration, Istanbul,Turkey. muratsalepcioglu@aydin.edu.tr, ORCID: 0000-0003-0280-9615

To cite this document

Tukel, O., Salepcioglu, M. A., (2021). Necessity of social fingerprint as an effective internal control system in Turkish businesses. PressAcademia Procedia (PAP), V.13, 111-112.

Permanent link to this document: http://doi.org/10.17261/Pressacademia.2021.1439

Copyright: Published by PressAcademia and limited licensed re-use rights only.

\section{ABSTRACT}

Purpose- Our purpose in this study is that businesses in Turkey can benefit from the SA8000 Social Responsibility Standardand Social Fingerprint rating as an internal control system in order to act effectively socially responsible.

Methodology- In our qualitative research, interview technique as a data collection tool will be applied on a voluntary basis. By analyzing the datas obtained as a result of the interviews, generalizations and conclusions of research for our assumption will be tried to be reached. As a sample, 5 businesses that do not certify SA8000 Social Responsibility Standard have been selected. 14 open-ended interview questions will be directed to 2 or 3 senior managers of the enterprise; the actions taken by the participants for social responsibility, the certifications they voluntarily implemented, the perceptions of the SA8000 standard, the motivations of social fingerprinting, the challenges they will face and the benefits to be gained will be questioned.

Findings- In the pilot study, participants said they had heard SA8000 standard and Social Fingerprint rating for the first time and they may be willing to apply it to their business. As a result of the research, it will be confirmed that SA8000 certification, which structurally guarantees social responsibility development to managers, and Social Fingerprint will provide an advantage in sustainability competition.

Conclusion- Adopting the SA 8000 certificate will help improve and improve the social responsibility of the business, as it means that an organisation must also take into account the working conditions of its employees, partners and suppliers and the social impact of these conditions

Keywords: Corporate social responsibility, SA8000 Social Responsibility Standards, social accountability, social fingerprint JEL Codes: M14, M48, E42, D71

\section{TÜRKIYE'DEKI işLETMELERDE ETKIN BíR iç KONTROL SISTEMI OLARAK SOSYAL PARMAK izi GEREKLILiĞi}

\section{ÖZET}

Amaç- Bu çalışmadaki amacımız Türkiye'deki işletmelerin etkin şekilde sosyal sorumlu davranabilmesi için bir iç kontrol sistemi olarak SA8000 Sosyal Sorumluk Standardı́ndan ve Sosyal Parmak İzi derecelendirmesinden faydalanabileceğidir.

Yöntem- Nitel araştırmamızda veri toplama aracı olarak mülakat tekniği, gönüllülük esasına uygun olarak uygulanacaktır. Mülakat sonucu elde edilen verilerin analizi yapılarak, genellemelere ve araştırmanın varsayım için doğurduğu sonuçlara ulaşılmaya çalışılacaktır. Örneklem olarak SA 8000 Sosyal Sorumluluk Standardını belgelendirmeyen 5 adet işletme seçilmiştir. Açık uçlu 14 adet mülakat sorusu işletmenin 2 veya 3 üst düzey yöneticisine yöneltilerek; katılımcıların sosyal sorumluluk için aldıkları aksiyonlar, gönüllülükle uyguladıkları belgelendirmeler, SA8000 standardı algıları, Sosyal Parmak İzi motivasyonları, karşılaşacakları zorluklar ve kazanılacak faydalar sorgulanacaktır.

Bulgular- Yapılan pilot çalışmada katılımcılar, SA8000 standardını ve Sosyal Parmak İzi derecelendirmesini ilk defa duyduklarını ve işletmelerine uygulayabilecekleri konusunda istekli olabileceklerini belirtmişlerdir. Araştırma sonucunda yöneticilere sosyal sorumluluk sürecini yapısal olarak garanti altına alan SA8000 belgelendirmesini ve Sosyal Parmak İzi'nin çalışanların motivasyonu ve bu doğrultuda sürdürülebilir rekabet konusunda avantaj sağlayacağı doğrulanmaya çalışılacaktır. 
Sonuç- SA 8000 sertifikasını benimsemek, bir kuruluşun çalışanlarının, ortaklarının ve tedarikçilerinin içinde bulunduğu çalışma koşullarına ve bu koşulların sosyal etkisini de dikkate alması gerektiği anlamına glmesi nedeniyle işletmenin sosyal sorumluluğunu geliştirmeye ve iyileştirmeye yardımcı olacaktır

Anahtar Kelimeler: Kurumsal sosyal sorumluluk, SA8000 Sosyal Sorumluluk Standardı, sosyal hesap verebilirlik, sosyal parmak izi JEL Kodları: M14 , M48, E42, D71

\section{KAYNAKÇA}

Chiarini A. \& Vagnoni E., (2017). Differences in implementing corporate social responsibility through SA8000 and ISO 26000 standards: Research from European manufacturing. Journal of Manufacturing Technology Management, 28 (4), $438-457$.

Eroğlu S.N. (2008). Sosyal Sorumluluk Denetimi \& SA 8000 Standardı ve Denizli ilinde Bir Uygulama. Yüksek Lisans Tezi, YÖK Ulusal Tez Merkezi, Pamukkale Üniversitesi.

Göbbels, J. \& Jonker, J. (2003). AA1000 and SA8000 compared: a systematic comparison of contemprary accountability standards, Managerial Auditing Journal, 18(1), 54-58.

Murmura, F. \& Bravi, L. (2020). Developing a corporate social responsibility strategy in India using the SA 8000 standards", Sustainability $12(4), 3481$

Rohitratana, K. (2002). SA 8000: A tool to improve quality of life. Managerial Auditing Journal, 17(2), 60-64.

Sartor, M. \& Orzes, G. (2019). SA 8000. Sartor, M. and Orzes, G. (Ed.) Quality Management: Tools, Methods, and Standards, Emerald Publishing Limited, Bingley, 265-280.

Guidance Document For Social Accountability 8000 (SA8000 $\left.{ }^{\circledR}: 2014\right) ; 01.05 .2021$

https://sa-intl.org/wp-content/uploads/2020/02/SA8000-2014-Guidance-Document.pdf 